\title{
Neoproterozoic Rosetta Gabbro from northernmost Arabian-Nubian Shield, south Jordan: Geochemistry and Petrogenesis.
}

Ghaleb H. Jarrar ${ }^{1}$, ${ }^{*}$ Robert J. Stern ${ }^{2}$, Thomas Theye ${ }^{3}$, Najel Yaseen ${ }^{1}$, Victoria Pease ${ }^{5}$, Nathan Miller ${ }^{6}$, Khalil M. Ibrahim ${ }^{4}$, Cees W. Passchier ${ }^{7}$; Martin Whitehouse ${ }^{8}$

1.* Geology Department, The University of Jordan, P.O.Box 13633, 11942 Amman, Jordan, corresponding author

2. Robert J. Stern, Geosciences Department U. Texas at Dallas, ROC 2.1, $800 \mathrm{~W}$. Campbell Rd, Richardson, Texas 75080, USA

3. Institut fuer Mineralogie und Kristallchemie, Universtität Stuttgart, Azenberg 18, D70174, Stuttgart, Germany.

4. Department of Earth Sciences and Environment, The Hashemite University, Zarqa, Jordan.

5. Department of Geological Sciences, Stockholm University, SE-10691 Stockholm, Sweden

6. The University of Texas at Austin, Jackson School of Geosciences , 2275 Speedway Stop C9000, Austin, TX 78712-172, USA

7. Institute of Geological Sciences, Johannes-Gutenberg University, Mainz, Germany.

8. Swedish Museum of Natural History, Box 50007SE-104 05 Stockholm Sweden

\begin{abstract}
An Ediacaran mafic intrusion of south Jordan is a distinctive appinitic igneous rock with a possibly unique texture, characterized by spherical clots up to $40 \mathrm{~mm}$ diameter composed of amphibole cores from which plagioclase euhedra radiate; we call it the Rosetta Gabbro. It is exposed as a small (ca. $750 \mathrm{~m}^{2}$ ) outcrop in the Neoproterozoic basement of south Jordan. A second outcrop of otherwise similar gabbro is located at about $400 \mathrm{~m}$ to the north of the Rosetta Gabbro, but it lacks the distinctive texture. The Rosetta Gabbro could represent a magma pipe intruding Aqaba Complex ( 600 Ma)
\end{abstract}


granitoids and metasediments of the Janub Metamorphic Complex (633 617 Ma). The gabbro is Ol- or QZ tholeiite with the following chemical characteristics $\left[\mathrm{SiO}_{2}=46.2-\right.$ 47.8 wt. $\% ; \mathrm{Al}_{2} \mathrm{O}_{3}=16.4-17.7$ wt. $\%, \mathrm{TiO}_{2}=1.70-2.82$ wt. $\%, \mathrm{Na}_{2} \mathrm{O}=1.27-2.83$ wt. $\%$. $\mathrm{K}_{2} \mathrm{O}=0.82-1.63$ wt. \%; $\mathrm{Mg} \#$ 58-63; $\Sigma \mathrm{REE}=70-117$ ppm; La/ $\mathrm{Yb} \sim 6$ to 8; $\mathrm{Eu} / \mathrm{Eu}^{*}=$ 1.05-1. 2). The investigated gabbro has the geochemical features of a continental flood tholeiitic basalt emplaced at a within-plate tectonic setting. Two varieties of amphibole are found: 1) large , 3-5 $\mathrm{mm}$ in size, brown ferri -titanian-tschermakite $\left(\mathrm{K}_{0.09}, \mathrm{Na}_{0.28}\right)\left(\mathrm{Na}_{0.20}, \mathrm{Ca}_{1.80}\right)\left(\mathrm{Mn}_{0.04}, \mathrm{Fe}^{3+}{ }_{1.1}, \mathrm{Mg}_{2.34}, \mathrm{Fe}^{2+}{ }_{0.90}, \mathrm{Ti}_{0.29}, \mathrm{Al}_{0.22}\right)\left(\mathrm{Al}_{1.85}, \mathrm{Si}_{6.15}\right) \mathrm{O}_{22}$ $(\mathrm{OH})_{1.95}$ of the calcic amphibole group riddled with opaques; and 2) acicular yellowishlight green ferrian-magnesiohornblende $\left(\mathrm{K}_{0.04}, \mathrm{Na}_{0.153}\right)\left(\mathrm{Ca}_{1.755}, \mathrm{Na}_{0.245}\right)\left(\mathrm{Fe}^{3+}{ }_{0.66}\right.$, $\left.\mathrm{Mn}_{0.01}, \mathrm{Fe}^{2+}{ }_{1.01}, \mathrm{Mg}_{3.03}, \mathrm{Ti}_{0.06}, \mathrm{Al}_{0.22}\right)\left(\mathrm{Al}_{1.03}, \mathrm{Si}_{6.97}\right) \mathrm{O}_{22}(\mathrm{OH})_{1.95}$. Scattered flakes of phlogopite also occur. Tabular radiating plagioclase $\left(\mathrm{An}_{64-79}\right)$ are complexly twinned, with broad lamellae that show no zoning. Laser-ablation ICP-MS analyses of amphibole and plagioclase reveal considerable variation in trace elements abundances, in spite of more subtle major element variations except for $\mathrm{TiO}_{2}$ in amphiboles. The REE in amphiboles show an order of magnitude variation with a concave-downward pattern and a positive Eu anomaly $\left(\mathrm{Eu} / \mathrm{Eu}^{*}=0.6-2\right)$, though far less pronounced compared to the $\left(\mathrm{Eu} / \mathrm{Eu}^{*}=5-45\right)$ of plagioclase. The 3D dandelion -like texture of the rosettas is broadly similar to "Chrysanthemum Stone", which is a diagenetic growth in sedimentary rock, but we can find no description of similar textures in igneous rocks. Formation of rosettas is thought to reflect loss of magmatic water resulting in supersaturation of plagioclase, which grew rapidly around amphiboles and may have floated in the magma. This implies magmatic evolution in the shallow (10 to $12 \mathrm{~km}$ deep) crust where temperatures were nevertheless in the range of ca 750 to $900{ }^{\circ} \mathrm{C}$.

\section{Introduction}

The Neoproterozoic basement complex of Jordan forms the northernmost extremity of the Arabian-Nubian Shield (ANS) and crops out over an area of about $1400 \mathrm{sq} \mathrm{km} \mathrm{east,}$ northeast and north of the Gulf of Aqaba as far as the southern shore of the Dead Sea

(Fig. 1A) (Bender, 1968). The ANS is one of the largest exposures of juvenile 
continental crust that has been formed as a consequence of plate tectonic processes. It evolved as the northern segment of the Neoproterozoic East African Orogen (EAO, 900$530 \mathrm{Ma}$ ) that extends from south to north for about $6000 \mathrm{~km}$ (Stern, 1994). It is generally regarded as a collage of juvenile volcanic arc terrains and associated ophiolite remnants, which were amalgamated during the assembly of Gondwana (e.g. Johnson et al., 2004; Meert, 2003; Stern, 1994). During the East African Orogeny, the ANS experienced multiphase deformation and metamorphism, ranging in grade from greenschist to upper amphibolite facies conditions (e.g. Jarrar et al. 2013; Abu El-Enen and Whitehouse, 2013). This was accompanied and followed by extensive plutonic and subordinate volcanic activity (Jarrar et al. 2003).

We describe here an interesting new occurrence of appinite from the ANS of southernmost Jordan. Appinite is defined as including melanocratic hornblende-rich syenite, monzonite, or diorite. In a review paper, Murphy (2013) discussed the role of water in the generation, emplacement, and crystallization history of mafic to felsic magmas and noted that a common feature of appinites is that they reflect crystallization from unusually water-rich mafic magmas. Appinites occur as stocks, pipes, dikes and sills and commonly form soon after the cessation of subduction. These rocks are genetically related to hornblendites and spessartite lamprophyres. Murphy (op.cit) suggested a broader definition for appinite suites as " a group of coeval plutonic and or hypabyssal rocks, ranging from ultramafic to felsic in composition, in which hornblende is the dominant mafic mineral and typically occurs both as large prismatic phenocrysts and in the finer grained matrix" .

The Rosetta Gabbro of southernmost Jordan is an appinite, but one with an unusual spherical texture that has not previously been reported. Spheroidal textures, generally referred to as globules, orbs, ocelli, varioles, and rapakivi are reported from diverse igneous lithologies; nevertheless, their origins remain a matter of debate (e.g. Ballhaus et al., 2015 and references therein). Liquid immiscibility has been advocated as a mechanism to explain spheroidal textures in some igneous rocks. Ballhaus et al. (2015) proposed that globular and orbicular textures my result from exsolution of a fluid phase at elevated temperature and pressure from $\mathrm{H}_{2} \mathrm{O}$ saturated mafic magmas. 
Field, petrography, major, trace and rare element chemistry, along with mineral chemistry including laser ablation MS analyses of amphibole and plagioclases of the Rosetta Gabbro appinitic suite with peculiar magmatic structure, recorded for the first time, is the subject of this study. Our study contributes to understanding the diversity of igneous structures and textures and how these form in water-rich mafic magmas. Below we report major and trace element compositions of the whole rocks and constituent minerals, and use these results to better understand how the Rosetta Gabbro formed.

2. Geologic setting and age constraints

The Neoproterozoic basement complex of south Jordan is comprised of igneous, sedimentary and metamorphic rocks that formed in the period 550-870 Ma (e.g., Jarrar, 1985; Ibrahim and McCourt, 1995; Jarrar et al. 2003, Jarrar et al. 2004; Jarrar et al. 2008, Jarrar et al., 2013; Yaseen et al., 2013). These rocks are broadly subdivided into two lithostratigraphic and intrusive divisions; namely, the older Aqaba and younger Araba complexes (Ibrahim and MCourt,1995) that are separated by the Araba Unconformity at about $605 \mathrm{Ma}$ (Powell et al., 2015). The Janub Metamorphic Suite (JMS) is part of the Aqaba complex (Fig.1B). The JMS is composed of metaconglomerates, meta-arkoses, cataclasites, mylonites, and cordierite-biotite hornfelses (Hassuneh, 1994). Using limited database of mineral chemistry, Habboush and Jarrar (2009) constrained the temperature of the contact metamorphism to be $500-545^{\circ} \mathrm{C}$. Mineral assemblages of the metasediments indicate low-pressure metamorphism $<4$ kbar. These P-T conditions are consistent with upper greenschist to lower amphibolite facies.

The investigated gabbro is one of three gabbroic lithologies forming the so-called Ayn-Al Hashim Gabbroic Suite (Abdelhamid et al. 1994). According to our field observations, the Rosetta Gabbro intrudes the Janub Metamorphic Complex and is intruded by Abu Jedda Granite (Fig. 2). Brook and Ibrahim (1987) dated the latter granite by $\mathrm{Rb} / \mathrm{Sr}$ whole rock techniques at $582 \pm 4 \mathrm{Ma}$. Abu Jedda granite is a biotite sub-solvus granite and consists of albite + microcline with rare perthite batches, quartz, biotite, and accessories of opaques, zircon and apatite. The CL images show oscillatory zoning and 
$\mathrm{Th} / \mathrm{U}$ ratio (0.48-0.72) typical of magmatic zircons. Five data points with acceptable degree of discordance yielded an age of $595.6 \pm 5 \mathrm{Ma}$ (Fig 3). This age is almost identical to the average ${ }^{207} \mathrm{~Pb} /{ }^{206} \mathrm{~Pb}$ age of $595.4 \pm 8 \mathrm{Ma}$, which we take as the crystallization age of the Abu Jedda granite (Table 1). Therefore, the Ayn-Al Hashim Gabbroic Suite is younger than $596 \pm 5 \mathrm{Ma}$ and thus part of the Araba Complex. Two of the Ayn-Al Hashim gabbroic bodies shown in Fig 1B and C are not shown on Ayn-Al Hashim map (map 3048I; scale 1:50000). Macrostructure and field aspects

The investigated Ayn Al Hashim gabbro with the amphibole-plagioclase rosettas intrudes as a small (ca. 750 sq meters) stock into the Janub Metamorphic Complex (Fig. 1 B and C). It was first described by Abdelhamid et al. (1994) as orbicular gabbro of the Ayn Al-Hashim Gabbroic Suite. A similar hornblende gabbro but lacking rosettas intrudes the same complex ca. 400 meter to the north (Fig. 1B). The rosettas are spherical to elliptical in shape and range in size from few millimeters up to about $5 \mathrm{~cm}$, typically consisting of tabular plagioclase grains radiating from an amphibole core. Photographs of gabbro in the field (Fig. 2C) and on polished slabs show both equatorial (with amphibole nuclei) and non-equatorial (lacking amphibole nuclei) sections through the rosettas (Fig. 4). To the best of our knowledge, this interesting structure has never been described before.

\section{Analytical techniques}

Four whole rock samples representative of the Ayn Al-Hashim Gabbroic Suite (HC-42, -43, and -44 from the Rosetta gabbro and one without rosettas (HC-31) from the northern gabbro were selected for detailed study. These were studied in thin section first. The software ImageJ-2 (Schneider et al. 2012) was used to calculate the ratio of plagioclase: amphiboles on the polished rock slabs. The four samples were analyzed for their major, trace and rare earth elements at the Australian Laboratory Services Arabia (ALS Arabia) in Jeddah, Saudi Arabia. Mineral chemistry was obtained using an electron microprobe at the Institut für Kristallchemie und Mineralogie, Universität Stuttgart, Germany. The plagioclase and the amphiboles of the rosettas were analysed for their 
major, trace and REE using the Laser-Ablation MS facility at the University of Texas at Austin, USA. More details about these methods are provided below.

\section{Whole-rock Analyses}

Samples powder was prepared using agate ball mill at the Geology Department, the University of Jordan. The major elements were determined using the Inductively Coupled Plasma-Atomic Emission Spectroscropy (ICP-AES); while trace elements including REE were measured by inductively coupled plasma mass spectrometry (ICPMS) after lithium borate fusion. Precision and accuracy were monitored against international reference standards and duplicate analyses and kept around $1 \%$ for major elements and better than 5\% for trace elements. Whole rock analytical results are reported in Table 2.

\section{Electron microprobe analyses}

Mineral compositions were determined using a CAMECA SX 100 WDS electron microprobe at the Institut für Kristallchemie und Mineralogie, Universität Stuttgart, Germany .Operating conditions were $15 \mathrm{kV}$ accelerating voltage and $10 \mathrm{nA}$ beam current. Natural minerals were used as standards. Counting time was $60 \mathrm{~s}$ for both peak and background. Errors range between 0.01 and 0.15 wt.\%. Representative mineral analyses are reported in Table X.

\section{LA-ICP-MS Analysis}

Trace element concentrations in Rosetta Gabbro amphibole, biotite and plagioclase were measured in two analytical sessions $(4 / 24 / 12,5 / 3 / 12)$ by LA-ICP-MS at the University of Texas at Austin $<\underline{\text { http://www.jsg.utexas.edu/icp-ms }}>$, using a New Wave Research UP 193-FX fast excimer (193nm wavelength, 4-6 ns pulse width) laser system coupled to an Agilent 7500ce ICP-MS. The laser system is equipped with a large format, two-volume laser cell, for direct sampling of the ablation plume with fast $(<1 \mathrm{~s})$ washout times. Laser ablation parameters optimized from representative test ablations were $45 \mathrm{~s}$ ablations using a $50 \mu \mathrm{m}$ diameter spot at $20 \%$ laser power (fluences of 4.06 and $3.63 \mathrm{~J} / \mathrm{cm}^{2}$ ), $10 \mathrm{~Hz}$ repetition rate, and a He cell flow of $300 \mathrm{~mL} / \mathrm{min}$. Pulse-to-pulse laser power variations were $<4.6 \%$ percent over the analysis period. All spots were preablated for $2 \mathrm{~s}$ using a $50 \mu \mathrm{m}$ spot, $7 \%$ laser power, and $10 \mathrm{~Hz}$ repetition rate to remove surface contamination. The ICP-MS operated at an RF power of $1600 \mathrm{~W}$ with an Ar 
carrier gas flows of 1.14 or $1.25 \mathrm{~L} / \mathrm{min}$. Oxide production rates, as monitored by $\mathrm{ThO} / \mathrm{Th}$ for NIST 612 , were $\leq 0.29 \%$. The quadrupole time-resolved method involved measurement of 33 analytes at 1-point per spectral peak, using the integration times of $10 \mathrm{~ms}\left({ }^{23} \mathrm{Na},{ }^{24} \mathrm{Mg},{ }^{25} \mathrm{Mg},{ }^{27} \mathrm{Al},{ }^{29} \mathrm{Si},{ }^{31} \mathrm{P},{ }^{39} \mathrm{~K},{ }^{43} \mathrm{Ca},{ }^{44} \mathrm{Ca},{ }^{45} \mathrm{Sc},{ }^{47} \mathrm{Ti},{ }^{51} \mathrm{~V},{ }^{53} \mathrm{Cr},{ }^{55} \mathrm{Mn},{ }^{57} \mathrm{Fe}\right.$, $\left.{ }^{60} \mathrm{Ni},{ }^{85} \mathrm{Rb},{ }^{88} \mathrm{Sr},{ }^{89} \mathrm{Y},{ }^{90} \mathrm{Zr},{ }^{93} \mathrm{Nb},{ }^{137} \mathrm{Ba}\right)$ and $30 \mathrm{~ms}\left({ }^{139} \mathrm{La},{ }^{140} \mathrm{Ce},{ }^{146} \mathrm{Nd},{ }^{147} \mathrm{Sm},{ }^{153} \mathrm{Eu},{ }^{157} \mathrm{Gd}\right.$, $\left.{ }^{163} \mathrm{Dy},{ }^{166} \mathrm{Er},{ }^{172} \mathrm{Yb},{ }^{175} \mathrm{Lu},{ }^{178} \mathrm{Hf}\right)$ and $30 \mathrm{~ms}$. The resulting sampling period $(0.6102 \mathrm{~s})$ corresponded to $90.1 \%$ detection time, enabling 73 measurements to be made within the $45 \mathrm{~s}$ dwell interval, conditions suitable for robust measurements (Longerich et al., 1996). A 30s gas blank interval was used between all laser measurements. Unknown spot analyses were bracketed hourly by triplicate analyses of laser ablation standards NIST612 and NIST-610 (Jochum et al., 2011). Measured analyte intensities were converted to elemental concentrations using Iolite software (Hellstrom et al., 2008), with NIST-612 as the primary calibration standard and ${ }^{29} \mathrm{Si}$ as the internal standard reference. Rosetta Gabbro Si concentrations for dark-colored amphibole and biotite (18.80 wt \%) and lightcolored amphibole and plagioclase $(23.37 \mathrm{wt} \%)$ were assigned based on stoichiometric estimates of 40 and $50 \mathrm{wt} \% \mathrm{SiO}_{2}$, respectively. Representative trace element analyses are given in Table $\mathrm{Y}$.

\section{$U-P b$ zircon Age determination techniques}

Ten zircon grains were picked and mounted together with $1065 \pm 0.3 \mathrm{Ma}$ Geostandard 91500 reference zircon (Wiedenbeck et al. 1995) in a resin desk, polished and gold-coated. Cathodoluminesence (CL) and secondary electron (SE) were used to reveal internal structure of the zircon grains and thus control the isotopic analysis on Hitachi S4300 scanning electron microscope (SEM) at Swedish Museum of Natural history (SMNH). The zircons separated from this granite are translucent, yellowish and euhedral. U-Th- $\mathrm{Pb}$ analysis was performed using secondary ion mass spectrometer (SIMS) type CAMECA IMS 1280 at SMNH. Analytical conditions and instrumental set up followed methods detailed by Whitehouse et al. (1997;1999). Recent lead contamination during sample preparation was assumed for the common $\mathrm{Pb}$ correction. The composition of the common $\mathrm{Pb}$ is calculated by using the Stacey and Kramers (1975) model for the present day (0.83). In this study the ${ }^{207} \mathrm{~Pb}$ corrected $\left({ }^{238} \mathrm{U} /{ }^{206} \mathrm{~Pb}\right)$ ages are used to interpret the isotopic results (calculated by projecting of the uncorrected data on 
the concordia from assumed common ${ }^{207} \mathrm{~Pb} /{ }^{206} \mathrm{~Pb}$ composition). Age interpretation and concordia diagrams were performed using Isoplot/Ex software (Ludwig, 2009).

\section{Results}

Below we summarize our results, first presenting the petrographic similarities and differences between the rosetta and non-rosetta types of Ayn-Al Hashim gabbro, then the results of whole-rock geochemical analyses and finally the results of mineral analyses.

\section{Petrography}

The Rosetta gabbro consists primarily of brown tschermakite extensively replaced by pale green magneisohornblende (Figs. 4A and 6A, B); and homogenous bytownite plagioclase, in particular those in the rosettas (Figs. 5A and 6C). The brown tschermakite is riddled with opaques. Some hypersthene and orthoclase grains are found. The opaques include both magnetite and ilmenite. Secondary chlorite and calcite are also present. Acicular grains of apatite up to $0.5 \mathrm{~mm}$ in length are common. The tabular bytownite crystals clearly grew after amphibole.

The non-rosetta hornblende gabbro also consists of brown tschermakite extensively replaced by light green magnesiohornblende (Fig. 4B), andesine to labradorite plagioclase, subordinate orthoclase, and ilmenite. Secondary chlorite is common. Zoned plagioclase with labradorite core is abundant. Ophitic and subophitic textures are common (Fig. 6D); therefore, plagioclase growth started before amphibole and then both grew together at the eutectic, in contrast to the inferred crystallization of amphibole before plagioclase for the Rosetta Gabbro. We calculated the amount of plagioclase as volume percentage on polished rock slabs of Rosetta Gabbro (Fig. 7). The amount of plagioclase ranges from 32 (for large rosettas) to $36.5 \%$ (rosettas plus groundmass plagioclase with grain size $\geq 0.1 \mathrm{~mm}$ ). Therefore, the ratio of plagioclase : hornblende $\sim 1: 2$.

\section{Geochemistry}




\subsection{Bulk Chemistry}

The chemical data for representative samples of the investigated suite are listed in Table 2. This gabbro is OL- or QZ tholeiite with $\mathrm{SiO}_{2}=46.2-49.1$ wt. $\%, \mathrm{Al}_{2} \mathrm{O}_{3}=16.35-$ 17.7 wt. $\%$, and $\mathrm{Na}_{2} \mathrm{O}=1.27-2.83$ wt. \%. The gabbros are relatively unfractionated, with up to 9.56 wt. $\% \mathrm{MgO}(\mathrm{Mg} \#=55-63)$ and up to $142 \mathrm{ppm} \mathrm{Ni}$ and $280 \mathrm{ppm} \mathrm{Cr}$. In spite of their relatively unfractionated compositions, the gabbros are enriched in incompatible elements, as is typical for igneous rocks of the Araba complex, with $\mathrm{TiO}_{2}=1.51-2.82 \mathrm{wt}$. $\%, \mathrm{~K}_{2} \mathrm{O}=0.82-2.36$ wt. $\%$, total $\mathrm{REE}=71-120 \mathrm{ppm}$ and strong light rare earth element enrichment $\left[(\mathrm{La} / \mathrm{Yb})_{\mathrm{N}} \sim 6\right.$ to 8$]$. Trace elements show evidence of plagioclase accumulation in some of the samples, with high Sr contents (460-847 ppm), elevated $\mathrm{Sr} / \mathrm{Y}(27-32)$ and positive europium anomalies $\left(\mathrm{Eu} / \mathrm{Eu}^{*}=1.05-1.2\right]$. The major elements data as well as HFSE classification and tectonic discrimination plots confirms that studied suite is a within-plate tholeiite (Fig. 8).

The chondrite-normalized patterns (Fig. 9A) are moderately enriched in LREE and show a weak positive Eu anomaly indicative of cumulate plagioclase. The MORBnormalized trace elements spider diagram (Fig. 9B) of the investigated suite is typical for continental flood basaltic tholeiites (Pearce, 1983; Wilson, 1989). The primitive mantle extended incompatibility plot (Fig. 9C) of the investigated suite shows a positive spike at the LILE of $\mathrm{Cs}, \mathrm{Rb}, \mathrm{Ba}, \mathrm{Pb}$ and $\mathrm{Sr}$ and a slight depletion at $\mathrm{Th}, \mathrm{Nb}$, Ta and $\mathrm{P}$.

\subsection{Mineral Chemistry}

A total of 112 analyses were obtained on amphiboles from the two gabbroic varieties (supplementary tables 1 and 2). Representative analyses of the various minerals are listed in Table 3. A wide range in major elements composition is obvious: Compared to the magnesio-hornblende, the tschermakite is poorer in silica (mean $=41.28 \pm 1.04 \mathrm{vs}$. $47.56 \pm 2.06$ wt. $\left.\% \mathrm{SiO}_{2}\right)$, richer in alumina $($ mean $=11.74 \pm 0.65$ vs. $7.25 \pm 1.81$ wt. $\%$ $\left.\mathrm{Al}_{2} \mathrm{O}_{3}\right)$, titanium $\left(\right.$ mean $=2.62 \pm 0.89$ vs. $0.58 \pm 0.36$ wt. $\left.\% \mathrm{TiO}_{2}\right)$, sodium $($ mean $=1.65 \pm$ 0.17 vs. $1.07 \pm 0.37$ wt. $\% \mathrm{Na}_{2} \mathrm{O}$ ), and potassium (mean $=0.49 \pm 0.12$ vs. $0.18 \pm 0.1$ wt. $\%$ $\mathrm{K}_{2} \mathrm{O}$ ), contains indistinguishable calcium (mean $=11.25 \pm 0.24$ vs. $11.20 \pm 0.62$ wt. $\%$ 
$\mathrm{CaO})$ and has a slightly lower $\mathrm{Mg \#}(72.4 \pm 0.1$ vs. $74.15 \pm 0.07)$. The two varieties (Rosetta gabbro and hornblende non-rosetta gabbro) contain tschermakite that differs in $\mathrm{SiO}_{2}, \mathrm{Al}_{2} \mathrm{O}_{3}, \mathrm{TiO}_{2}$, and alkalies

The amphibole classification following recommendations by Leake et al. (2004) is based on the general chemical formula

$\mathrm{A}_{0-1} \mathrm{~B}_{2} \mathrm{C}_{5}{ }^{\mathrm{VI}} \mathrm{T}_{8}{ }^{\mathrm{IV}} \mathrm{O}_{22}(\mathrm{OH}, \mathrm{F}, \mathrm{Cl})_{2}$

Since water and halogen contents are not determined by EMP, the amphibole formula is calculated on the basis of 23 oxygens and the $\mathrm{Fe}^{3+} / \mathrm{Fe}^{2+}$ following the procedure proposed by Schumacher (1997) and using the software WinAmphcal by (Yavus, 2007). For amphiboles analyzed from the Ayn-Al Hashim Gabbroic Suite, $(\mathrm{Ca}+\mathrm{Na})_{\mathrm{B}}>1.60$ and $\mathrm{Na}_{\mathrm{B}}$ $<0.5$, so all amphiboles are calcic with $\mathrm{Si}^{\mathrm{IV}}$ between 5.890 and 7.489 apfu. Furthermore, on the $\mathrm{Mg} /\left(\mathrm{Mg}+\mathrm{Fe}^{2+}\right)$ vs Si classification diagram, amphiboles from rosetta bearing and hornblende gabbros range from ferri -titanian-tschermakite (Fig. 10).

$\left(\mathrm{K}_{0.09}, \mathrm{Na}_{0.28}\right)\left(\mathrm{Na}_{0.20}, \mathrm{Ca}_{1.80}\right)\left(\mathrm{Mn}_{0.04}, \mathrm{Fe}^{3+}{ }_{1.1}, \mathrm{Mg}_{2.34}, \mathrm{Fe}^{2+}{ }_{0.90}, \mathrm{Ti}_{0.29}, \mathrm{Al}_{0.22}\right)\left(\mathrm{Al}_{1.85}, \mathrm{Si}_{6.15}\right) \mathrm{O}_{22}$ $(\mathrm{OH})_{1.95}$ to ferrian-magnesiohornblende

$\left(\mathrm{K}_{0.04}, \mathrm{Na}_{0.153}\right)\left(\mathrm{Ca}_{1.755}, \mathrm{Na}_{0.245}\right)\left(\mathrm{Fe}^{3+}{ }_{0.66}, \mathrm{Mn}_{0.01}, \mathrm{Fe}^{2+}{ }_{1.01}, \mathrm{Mg}_{3.03}, \mathrm{Ti}_{0.06}, \mathrm{Al}_{0.22}\right)\left(\mathrm{Al}_{1.03}, \mathrm{Si}_{6.97}\right)$ $\mathrm{O}_{22}(\mathrm{OH})_{1.95}$.

in composition, except for some analyses that fall in the actinolite field. Rosetta gabbro has amphiboles with generally higher $\mathrm{Mg} /\left(\mathrm{Mg}+\mathrm{Fe}^{2+}\right)$ (Fig. 10).

The plot of $\mathrm{Al}^{\mathrm{VI}}$ (C site) vs $\mathrm{Al}^{\mathrm{IV}}$ (T site) in Ayn-Al Hashim Gabbroic Suite (Fig. 11) shows that $\mathrm{Al}$ is preferred in the tetrahedral site. Furthermore, the Ti and $(\mathrm{Na}+\mathrm{K})^{\mathrm{A}}$ correlate positively with tetrahedral Al (Fig 11). These features and the negative correlation between $(\mathrm{Na}+\mathrm{K})_{\text {A }}$ vs. Si (Fig. 11 ) implies the dominance of edenite type substitution $\left[(\mathrm{Na}+\mathrm{K})^{\mathrm{A}}+\mathrm{Al}^{\mathrm{IV}}=\mathrm{Si}^{\mathrm{IV}}+(\square)^{\mathrm{A}}\right]$; Ti-tschermak substitution $\left[\mathrm{Al}^{\mathrm{IV}}+\mathrm{Ti}^{\mathrm{IV}}=\mathrm{Si}^{\mathrm{IV}}\right.$ $\left.+\mathrm{Mg}^{\mathrm{VI}}\right]$ and Al-tschermak substitution $\left[\mathrm{Al}^{\mathrm{IV}}+\mathrm{Al}^{\mathrm{VI}}=\mathrm{Si}^{\mathrm{IV}}+\mathrm{Mg}^{\mathrm{VI}}\right]$ during the replacement of the tschermakite by magnesiohornblende. 
The efficiency of the LA-ICP-MS technique for mapping igneous minerals for their trace and REE elements content have been recently documented (e.g Ubide et al., 2015). The early crystallizing amphibole (tschermakite) has trace element compositions that are distinct from late-forming magnesiohornblende (Supplementary Table 3). Relative to magnesiohornblende, tschermakite contains more Sc (Mean $=49.9 \pm 28.9$ vs. $17.9 \pm 17.8$ ppm $), \mathrm{V}($ Mean $=529.4 \pm 116.8$ vs. $221.1 \pm 96.0$ ppm $), \mathrm{Rb}($ Mean $=6.6 \pm 12.7$ vs. $0.44 \pm 0.90 \mathrm{ppm}), \mathrm{Sr}(\mathrm{Mean}=170.3 \pm 94.2 \mathrm{ppm}$ vs. $38.4 \pm 45.6 \mathrm{ppm}), \mathrm{Y}(30.5 \mathrm{ppm}$ vs. $10.9 \pm 5.6 \mathrm{ppm}), \mathrm{Zr}($ Mean $=89.5$ vs. $20.2 \pm 20.3 \mathrm{ppm}), \mathrm{Nb}($ Mean $=12.2 \pm 3.6$ vs

$2.34 \pm 1.75 \mathrm{ppm}), \mathrm{Ba}($ Mean $=86.9 \pm 61.0$ vs. $15.3 \pm 45.3 \mathrm{ppm}), \mathrm{Hf}($ Mean $=3.18 \pm 1.49 \mathrm{ppm}$ vs. $0.70 \pm 0.73 \mathrm{ppm}$, and REE (Mean $94.3 \pm 34.4$ vs. $39.0 \pm 14.8$ ppm). Tschermakite contains less $\mathrm{Cr}($ Mean $=84.3 \pm 111.5$ vs. $143.8 \pm 73.0 \mathrm{ppm})$ and $\mathrm{Ni}($ Mean $=169.3 \pm$ 102.5 vs. $285.4 \pm 73.0 \mathrm{ppm})$.

A distinctive positive relationship exists between $\mathrm{V}$ concentration and $\mathrm{TiO} 2, \mathrm{Zr}$, total REE (Fig. 12). Furthermore, Zr correlates negatively with Eu anomaly, $\mathrm{Cr}$ and $\mathrm{Ni}$. The latter elements correlates positively with each other (Fi.g 12 ), and with $\mathrm{MgO}$ content (diagram not shown). Similar behavior of trace elements in crystallizing amphiboles has been observed by Muerer and Claeson (2002). The highest concentrations of REE are encountered in amphiboles with highest $\mathrm{V}$ and $\mathrm{TiO} 2$ contents i.e. in tschermakites.

The tschermakites are enriched in total REE relative to the magnesiohornblendes. However, the chondrite-normalized plots of amphiboles (Fig. 13A \&B)from both varieties are bowed up in the middle with negative and positive Eu anomalies $\left(\mathrm{Eu} / \mathrm{Eu}^{*}\right.$ 0.55 to 1.25 for tschermakite and up to 2.0 for magnesiohornblende. The primitive mantle normalized incompatibility plots for amphiboles are also concave downwards with negative anomalies at $\mathrm{Rb}, \mathrm{Ba}, \mathrm{K}, \mathrm{Sr}$, and $\mathrm{Zr}$, though much pronounced for magnesiohornblende (Fig. 13D \&E).

The plagioclase of the rosetta gabbro is dominantly bytowonite ( $\mathrm{An}_{72-77}$ ) with some labradorite $\left(\mathrm{An}_{62-64}\right)$. On the other hand, the plagioclase in the non-rosetta gabbro ranges from andesine to labradorite $\left(\mathrm{An}_{39-58}\right)$. The plagioclase has much lower total REE's 
(3.57-19.23; average $7.47 \pm 4.15)$ and a pronounced positive $\mathrm{Eu}$ anomaly (Eu/Eu* up to 48) (Fig. 13C).

\section{Discussion}

The rosetta texture we describe here is an unusual texture that testifies to an unusual style of crystallization of amphibole and plagioclase that grew in mafic magma. Clearly, amphibole crystallized first, then plagioclase nucleated on its surface and grew outward. This must have happened while amphiboles were suspended in magma. Outward growth of plagioclase must also have occurred while suspended in magma. Somewhat similar textures were identified by Yazgan and Mason (1988), who described layers of troctolite in orbicular gabbro from near Baskil, southeastern Turkey. These few millimeter thick layers consist of radiating prismatic olivine $\left(\mathrm{Fo}_{81}\right)$ and plagioclase $\left(\mathrm{An} n_{91}\right)$.

One might be tempted to call the rosettas "spherulites", because the latter are also radiating arrays of acicular crystals which are common in glassy felsic volcanic rocks (Vernon, 2008), however this is inappropriate because spherulitic growth reflects devitrification of glassy felsic rocks such as obsidian (Ewart, 1971), which is fundamentally different than the magmatic growth that formed the rosettas.

Spheroidal textures in igneous rocks interpreted to have formed in magmas are called by various names including globules, orbs, orbicules, ocelli, and varioles. These have been interpreted in terms of liquid immiscibility, cavity filling by late-stage liquids, magma mingling, magma mixing, partial assimilation, exsolution of a fluid phase from hydrous magma, and rapid undercooling by volatile loss (e.g., Ballhaus et al., 20015 and references therein). None of these terms satisfactorily describes the texture and mineral compositions observed. For this reason, we feel justified introducing a new term into the petrologic literature. How did this unusual texture form? Below we consider various lines of evidence.

\section{A. Pressure and Temperature}

The temperatures obtained from plagioclase-tschermakite pairs are: $886 \pm 21.62$ and $905.36 \pm 41^{\circ} \mathrm{C}$ (Supplementary Table $1 \& 2$ ) for hornblende gabbro and Rosetta 
Gabbro, respectively. In contrast, plagioclase-magnesiohornblende pairs yield lower temperatures of equilibration $746 \pm 62$ and $829 \pm 25^{\circ} \mathrm{C}$ for hornblende gabbro and Rosetta Gabbro, respectively.

The pressure of crystallization as deduced from the Al content in amphiboles is as follows: tschermakite: $6.40 \pm 0.76$ and $6.28 \pm 0.99 \mathrm{kbar}$ for hornblende gabbro and rosetta gabbro, respectively. On the other hand, magnesiohornblende documents lower pressures; namely $2.49 \pm 0.89$ and $3.29 \pm 0.62 \mathrm{kbar}$ for both varieties.

Cationic substitutions in amphiboles are temperature-sensitive as deduced from natural and experimental assemblages (e.g. Blundy and Holland, 1990; Holland and Blundy, 1994; Shane and Smith, 2013; Kiss et al., 2014). Shane and Smith (2013) concluded that nearly all of $\mathrm{Al}$ atomic substitutions in amphiboles can be accounted for by temperature-sensitive edenite and Ti tschermak exchange mechanisms with a minor role played by the pressure sensitive Al-tschermak substitution, consequently Alamphibole barometers can produce erroneous results.

The above calculated pressures are based on the empirical and experimental Alhornblende barometers suggested by Hammarstrom (1986) and Anderson and Schmidt (1995) which require a critical mineral assemblage: plagioclase + hornblende + biotite + $\mathrm{K}$-feldspar + quartz + titanite. The investigated gabbro lacks titanite and quartz, whereas phlogopitic mica and K-feldspar are very rare. Larocque and Canil (2010) proposed an empirical barometer that is based on the octahedral aluminum in the amphibole which has the following form:

$\mathrm{Al}^{\mathrm{VI}}=0.056 * \mathrm{P}-0.008$ (pressure in kbar). Kraweczynski et al. (2012) updated the above equation using additional experimental data and suggested the following barometer Formatted: Font: (Default) Times New Roman, 12 pt, Swedish (Sweden) that is independent of the above mineral assemblage:

$$
\mathrm{P}(\mathrm{MPa})=1,675^{*} \mathrm{Al}^{\mathrm{VI}}-48
$$

We used the octahedral Al from tschermakite and magnesiohornblende which for both varieties average 0.22 ( $a p f u$ ) to calculate the pressure of equilibration, and obtained 3.75 and $3.20 \mathrm{kbar}$, applying the two calibrations, respectively. These pressure values correspond to 12.48 to $10.66 \mathrm{~km}$, respectively. This depth estimate is reasonable bearing in mind that the investigated gabbro is intruding in greenschist facies rocks of the Janub Metamorphic Complex. 
We conclude that the amphibole - cored rosettas formed while suspended in a mafic magma body $\sim 600 \mathrm{Ma}$. It is clear that tschermakitic amphibole crystallized first. As these tschermakites grew, they slowly sank in the mafic magma body. Tschermakites were overgrown by magnesiohornblende, indicating a change in magma composition. From the trace element concentrations in the two amphiboles, it appears that earlyformed tschermakite was in equilibrium with a significantly more fractionated magma than was late-formed magnesiohornblende. This strongly suggests that tschermakite formed in equilibrium with fractionated mafic magma and that the growth of to magnesiohornblende resulted from recharge of the magma body with primitive, mantlederived mantle.

\section{B. Magmatic Water and Plagioclase Crystallization}

Experimental data indicates that increased water pressure in magma expands hornbende stability relative to olivine, pyroxene and plagioclase (e.g. Moore and Carmichael, 1998; Kraweczynski et al., 2012). Greater magmatic water content also favors depolymerization of the melt and consequently reduces magma viscosity, further facilitating rapid growth of hornblende (e.g., Meysen, 1988). Though the petrological significance of $\mathrm{H}_{2} \mathrm{O}$ in these magmas is clear, the source of this water is still a matter of debate (Murphy 2013 and references therein). Nevertheless, many investigations indicate that the mantle-derived mafic magma inherits its water from derived from metasomatized mantle above a subduction zone (Fowler et al., 2001).

Experimental data on amphibole stability in mafic magmas demonstrate that the first amphibole appearing at $5 \mathrm{kbar}$ has an $\mathrm{Al}_{2} \mathrm{O}_{3}$ content of $12.5 \mathrm{wt} \%$ with lower contents at pressures of $2 \mathrm{kbar}$ since it co-precipitates with plagioclase. Plagioclase crystallization depends on magma $\mathrm{H}_{2} \mathrm{O}$ content (e.g. Sisson and Grove, 1993). There is a switch in the order of crystallization between plagioclase and amphibole at about $3 \mathrm{kbar}$ (Kraweczynski et al., 2012) and at higher pressures, plagioclase crystallizes after hornblende. The growth of plagioclase crystals that nucleated on magnesiohornblende cores may have been driven by volatile loss from a hydrous magma in a shallow magma conduit. Nucleation and growth of crystals in magmatic systems depend on the degree of undercooling or supersaturation of the magma (e.g. Higgins, 2006). The growth rate of 
plagioclase in basaltic systems has been constrained between $10^{-9}$ and $10^{-11} \mathrm{~mm} / \mathrm{s}$ for lower and higher degrees of undercooling, respectively (e.g. Cashman, 1993; Higgins and Chandrasekharam, 2006). The largest plagioclase in the rosettas has a length of ca 15 $\mathrm{mm}$. Accordingly, the maximum crystallization time of these rosettas varied between $\sim 500$ to $\sim 50,000$ years. Taking an average growth rate of $10^{-10} \mathrm{~mm} / \mathrm{s}$ suggests a crystallization time of $\sim 5,000$ years. Radial growth of plagioclase around a magnesiohornblende nucleus implies oversaturation, perhaps caused by loss of the water-rich fluid phase as a consequence of hornblende crystallization and magmatic degassing.

\section{Suspension in magma}

The nearly spherical shape of the rosettas and the lack of evidence for close packing (Fig. 2) indicate that they grew while suspended in magma. This is very likely because the density of plagioclase is very close to that of basaltic magma, especially ironrich magmas (Scoates, 1999). The rosettas may have been slightly more dense than the surrounding mafic magma and sunk slowly in it, or they may have been slightly less dense than the magma and risen slowly through it. We do not know the composition of the magma, the whole rock compositions listed in Table 2 are mixtures of magma and rosettas. If we take the average $\mathrm{Fe}_{2} \mathrm{O}_{3}$ of the 3 Rosetta gabbro samples (10.4 wt.\%) and assume that $30 \%$ of the rock is rosettas with 0 wt. $\% \mathrm{Fe}_{2} \mathrm{O}_{3}$, then the magma contained $\sim 15$ wt. $\% \mathrm{Fe}_{2} \mathrm{O}_{3}$; this would have been significantly denser than most plagioclase (Sparks and Huppert, 1984). Because hornblende has density 3.0-3.4 g/cc, these would have sunk in the magma (density $\sim 2.7-2.75 \mathrm{~g} / \mathrm{cc}$ ), but the density of rosettas would have decreased as plagioclase (plagioclase $\left(\mathrm{An}_{64-79}\right)$ with a density of $\sim 2.6 \mathrm{~g} / \mathrm{cc}$. It is possible that the rosettas sank at first but as plagioclase continued to grow, they reached neutral buoyancy and then became buoyant. One can imagine a scenario whereby sinking hornblendes slowed their descent as they became coated with plagioclase, stopping their descent after they reach a certain size, then begin to rise in the magma. Whether or not this scenario is correct, it seems clear that the rosettas attained their remarkable form while growing in magma.

\section{Conclusions}


The $\sim 600$ Ma Rosetta Gabbro of southern Jordan is characterized by a unique igneous texture consisting of tschermakite cores surrounded by rims of magnesiohornblende, from which euhedral plagioclase laths extend radially, creating nearly spherical bodies up to a few centimeters in diameter. These rosettas formed while suspended in mafic magma and may have floated in this magma.

Fig. 14 summarizes our understanding of the formation of the Rosetta Gabbro and non-rosetta hornblende gabbro. Panel A shows two mafic intrusions that were emplaced $\sim 600 \mathrm{Ma}$. The magma body that went on to become the Rosetta Gabbro was water-rich but was able to lose magmatic volatiles (especially water) by degassing, perhaps via a volcanic conduit. The magma body that did not develop rosettas may have been drier and/or one that could not easily degas. Both magma bodies crystallized Tschermakite early but plagioclase crystallization was suppressed in the magma body that became Rosetta Gabbro because of high magmatic water pressures. The other (non-rosetta) magmatic body crystallized plagioclase along with Tschermakite. In both magma bodies, magnesiohornblende crystallized around Tschermakite cores. In the case of the Rosetta Gabbro intrusion, the growth of magnesiohornblende reflected influx of more primitive mafic magma, which heated fractionated magma and caused it to degas, leading to a decrease in magmatic water pressure. Degassed magma became supersaturated in plagioclase, which nucleated on hornblende crystals suspended in magma. Once begun, radial growth of plagioclase was rapid, lowering density of hornblende-plagioclase rosettas and allowing them to remain suspended in magma. At some point, the magma body cooled and crystallized, freezing rosettas in place. Shortly afterwards $\sim 596 \mathrm{Ma}$, the Abu Jedda granite intruded gabbroic bodies. Subsequently $\sim 10 \mathrm{~km}$ of erosion in Late Ediacaran time brought the magma chamber to the surface.

Acknowledgements

Ghaleb H. Jarrar and Najel Yaseen are grateful to the University of Jordan for logistic and financial support. This study was partially carried out while the senior author was on a sabbatical leave as a Fulbright scholar at the Jackson School of Geosciences, UTA, Austin, USA. The support offered to him by Elizabeth Catlos and William Carlson is highly appreciated. The stay of the senior author at NORDSIM facility was supported by 
the JEBEL project and Swedish Research Council grants to V. Pease and M.J.

Whitehouse. This is NORDSIM publication ..... This is UTD Geosciences contribution \# 


\section{References}

Abdelhamid, Gh, Kh. Ibrahim, and Cedric Mortimer. 1994. The geology of Ayn Al Hashim, Jabal Al Mubarak and Al Yamaniyya. Map sheet no. 3048, 3048 IV, and 2948I. Natural Resources Authority, Bulletin 27.

Abu-El-Enen, M. M. and Martin J. Whitehouse. 2013. The Feiran-Solaf metamorphic complex, Sinai, Egypt: Geochronological and geochemical constraints on its evolution. Precambrian Research 239, 106-125.

Anderson, J.L. and Smith D.R. 1995. The effect of temperature and fO2 on the Al-inhornblende barometer. American Mineralogist 80, 549-559.

Ballhaus, C., R, Fonseca, C. Muenker, M., Kirchenbaur, and A. Zirner 2015. Spheroidal textures in igneous rocks-Textural consequences of $\mathrm{H} 2 \mathrm{O}$ saturation in basaltic melts. Geochemica Cosmochemica Acta 167, 241-252.

Bender, F. 1968. Geologie von Jordanien. Beiträge zur regionale Geologie. 230 pp. Berlin Bornträger.

Birbaum, K., Frick, D.A., Gunther, D., and Enzweiler, J., 2011, Determination of Reference Values for NIST SRM 610-617 Glasses Following ISO Guidelines: Geostandards and Geoanalytical Research 35, p. 397-429.

Brook, M and Ibrahim, K. 1987. Geochronological and isotope geological investigation of the Aqaba basement complex of southern Jordan. British Geological Survey Isotope Geol. Unit Report 48.

Blundy, J. and Holland, T.J.B. 1990. Calcic amphibole equilibria and a new amphibole-plagioclase geothermometer. Contributions to Mineralogy and Petrology 104, 208-224.

Chashman, K.V. 1993. Relationship between plagioclase crystallization and cooling rates in basaltic melts. Contributions to Mineralogy and Petrology 113, 126143.

Ewart, A. 1971. Chemical changes accompanying spherulitic crystallization in rhyolitic lavas, Central Volcanic Region, New Zealand, Mineralogical Magazine, 38, 424-434. 
Fowler, M.B., Henney, P.J., Darbyshire, D.P.F. and Greenwood, P.B. 2001.

Petrogenesis of high Ba-Sr granites: the Rogart pluton, Sutherland. Journal of the Geological Society 158, 521-553.

Habboush, M. and Jarrar, G. (2009). Petrology and Geochemistry of the Metasediments of the Janub Metamorphic Suite, Southern Jordan: Implications for Geothermobarometry and Economic Potential. Jordan Journal of Earth and Environmental Sciences. 2, 1:7-17.

Hassuneh, M. Hassuneh, M. 1994. Geological, Petrological and geochemical investigation of the Janub metamorphic suite rocks in Wadi Es-Sabil, Ain ElHasheem area, SE Aqaba. Unpubl. M. Sc. Thesis, The University of Jordan.

Hammarstrom, J.M. and Zen, E-an. 1986. Aluminum in hornblende: an empirical igneous geobarometer. American Mineralogist 71, 1297-1313.

Hellstrom, J.C., Paton, C., Woodhead, J.D., and Hergt, J., 2008, Iolite: software for spatially resolved LA-(quad and MC) ICPMS analysis: Mineralogical Association of Canada Short Course, v. 40, p. 343-348.

Higgins M.D. 2006. Quantitative textural measurements in igneous and metamorphic petrology. Cambridge. Cambridge University Press. 265 pp.

Higgins, M.D. and Chandrasekharam, D. 2007. Nature of subvolcanic magma chambers, Deccan Province, India: Evidence from quantitative textural analysis of plagioclase megacrysts in the Giant Plagioclase Basalts. Journal of Petrology 48, 885-900.

Holland, T.J.B. and J. Blundy 1994. Non-ideal interactions in calcic amphiboles and their bearing on amphibole-plagioclase thermometry. Contributions to Mineralogy and Petrology 116, 433-447.

Ibrahim, K.M. and McCourt, W.J. (1995). Neoproterozoic granitic magmatism and tectonic evolution of the northern Arabian Shield: evidence from South West Jordan. Journal of African Earth Science 20, 103-118.

Irvine TN and Baragar WRA (1971) A guide to the chemical classification of the common volcanic rocks. Canadian Journal of Earth Sciences 8, 523-548.

Jarrar, G. (1985). Late Proterozoic crustal evolution of the Arabian Nubian Shield in the Wadi Araba area, SW-Jordan. Geol J. B 61: 3-87. 
Jarrar, G., Stern, R.J., Saffarini, G. and Al-Zubi, H. (2003). Late- and post-orogenic Neoproterozoic intrusions of Jordan: implications for crustal growth in the northernmost segment of the East African Orogen. Precambrian Research 123, 295-319.

Jarrar G.H., Saffarini G., Baumann A. ,Wachendorf, H. (2004). Origin, age and petrogenesis of Neoproterozoic composite dikes from the Arabian-Nubian Shield, SW Jordan. Geological Journal 39, 157-178

Jarrar G.H, Manton, WI, Stern R J, Zachmann D (2008) Late Neoproterozoic A-type granites in the northernmost Arabian-Nubian Shield formed by fractionation of basaltic melts. Chem der Erde 68, 295-312.

Jarrar, G., T. Theye, N. Yaseen, M., Whitehouse, V. Pease, and C. Paschier. 2013. Geochemistry and P-T-t evolution of the Abu-Barqa Metamorphic Suite, SW Jordan, and implications for the tectonics of the northern Arabian-Nubian Shield. Precambrian Research 239, 56-78.

Johnson, P.R., Kattan, F.H. and Al-Saleh, A.M. (2004). Neoproterozoic ophiolites in the Arabian Shield: Field relations and structure. In: Kusky, T. M. Precambrian Ophiolites and related rocks. Developments in Precambrian Geology, V. 13. (K. C. Condie, Series Editor), Elsevier B. V.

Kiss, B., S. Harangi, T. Ntaflos, P.R.D. Mason, and E. Pál-Molnár. 2014. Amphibole perspective to unravel pre-eruptive processes and conditions in volcanic plumbing systems beneath intermediate arc volcanoes: a case study from Ciomadul volcano (SE Carpathains). Contributions to Mineralogy and Petrology 167.986.

Leake, B. E. et al. 2004. Nomenclature of amphiboles: Additions and revisions to the International Mineralogical Association's amphibole nomenclature. European Journal of Mineralogy 16, 191-196.

Larqocque J. and Canil, D. 2010. The role of amphibole in the evolution of arc magmas and crust: the case from the Jurassic Bonanza arc section, Vancouver Island, Canada. Contributions to Mineralogy and Petrology 159, 475-492.

Le Maitre RW, Bateman P, Dudek A, Keller J, Lameyre J, Le Bas MJ, Sabine, PA, Schmid R, Sorensen H, Streckeisen A, Woolley AR and Zanettin B (1989) A Classification of Igneous Rocks and Glossary of terms: Recommendations of the 
International Union of Geological Sciences Subcommission on the Systematics of Igneous Rocks. Blackwell Scientific Publications, Oxford, U.K.

Meert, J.G. 2003. A synopsis of events related to the assembly of eastern Gondwana.

Tectonophysics, 362, 1-40.

Meurer, W.P. and Claeson, D.T. 2002. Evolution of crystallizing interstitial liquid in arcrelated cumulate determined by LA ICP-MS mapping of a large amphibole oikocryst. Journal of Petrology, 43, 607-629.

Moore, G. and Carmichael, I.S.E. 1998. The hydrous phase equilibria (up to $3 \mathrm{kbar}$ ) of an andesite and basaltic andesite from western Mexico: Constraints on water contentand conditions of phenocryst growth. Contributions to Mineralogy and Petrology 130, 304-319.

Meysen, B.O. 1988. Structure and properties of of silicate melts. Elsevier, Amsterdam.

Pearce, J.A. 1983. The role of sub-continental lithosphere in magma genesis at destructive plate margins. In Continental basalts and mantle xenoliths. C. Hawkesworth and M. Norry (eds), 230-249.

Pearce J.A. and Norry M.J. 1979. Petrogenetic implications of Ti, Zr, Y, and Nb variations in volcanic rocks. Contribution to Mineralogy and Petrology 69, 33-47.

Schumacher, J.C. 1997. Appendix 2: The estimation of ferric iron in the electron microprobe analysis of amphiboles. Canadian Mineralogist 35, 238-246.

Scoates, J. S., 1999. The Plagioclase-Magma density Paradox Re-examined and the Crystallization of Proterozoic Anorthosites. J. Petrology 41, 627-649.

Sparks, R. S. J., and Huppert, H. E., 1984. Density changes during the fractional crystallization of basaltic magmas: Fluid dynamic implications. Contributions to Mineralogy and Petrology 85, 300-309.

Stern, R.J. 1994. Arc assembly and continental collision in the Neoproterozoic East African Orogen. Implications for the consolidation of Gondwanaland, Annual Review. Earth Planetary Science 22, 319-351.

Krawczynski, M., T. Grove, and H. Behrens. 2012. Amphibole stability in primitive arc magmas: effects of temperature, $\mathrm{H}_{2} \mathrm{O}$ content and oxygen fugacity. Contributions to Mineralogy and Petrology. 164,317-339. 
Ludwig, K.R., 2009. Isoplot/Ex rev. 3.5. A geochronological toolkit for Microsoft Excel. Berkeley Geochronology center, Special Publications.

Murphy, J.B. 2013. Appinite suites: A record of the role of water in the genesis, transport, emplacement and crystallization of magma. Earth Science Reviews, 119, 35-59.

Murphy, J.B., S. A. Blais, M. Tubrett, D. McNeil, and M. Middleton. 2012.

Microchemistry of amphiboles near the roof of a mafic magma chamber: Insights into high level melt evolution. Lithos, 148, 162-175.

Schneider, C. A., Rasband, W. S. \& Eliceiri, K. W. 2012. NIH Image to ImageJ: 25 years of image analysis, Nature methods 9, 671-675.

Shane, P. and V. Smith. 2013. Using amphibole crystals to reconstruct magma storage temperatures and pressures for the post-caldera collapse volcanism at Okataina volcano. Lithos, 159-170.

Sisson, T. W. and Grove, T.L. 1993. Experimental investigations of the role of H2O in calc-alkaline differentiation and subduction zone magmatism. Contributions to Mineralogy and Petrology, 117, 143-166.

Stacey, J.A. and Kramers, J.D., 1975. Approximation of terrestrial lead isotope evolution by a 2-stage model. Earth and Planetary science Letters, 36: 359-362

Sun, S. and W.F. McDonough, 1989. Chemical and isotopic systematics of oceanic basalt: implications for mantle composition and processes, in Magmatism in the Ocean Basins edited by A. D. Saunders and M.J Norry, Geol Soc Special publ., 42,313-345.

Ubide, T. C.A. McKenna, D.M.Chew, and B. S. Kamber 2015. High-resolution LA-ICPMS trace element mapping of igneous minerals: In search fo magma history, Chemical Geology 409, 157-168.

Vernon, R.H. 2008. A practical guide to rock microstructure. Cambridge University Press. 594 pp.

Whitehouse, M. J., Claesson, S., Sunde, T., Vestin, J. 1997. Ion-microprobe U-Pb zircon geochronology and correlation of Archean gneisses from the Lewisian Complex 
of Gruinard Bay, north-west Scotland, Geochimica et Cosmochimica Acta 61:4429-4438.

Whitehouse, M. J., Kamber, B.S., Moorbath, S. 1999. Age significance of U-Th-Pb zircon data from early Archaean rocks of west Greenland- a reassessment based on compined ion microprobe and imaging studies. Chemical geology 160: 201-224.

Wiedenbeck, M., Allé, P., Corfu, F., Griffin,W. L., Meier, M., Oberli, F., von Quadt, A., Roddick, J. C., Spiegel, W. 1995. Three natural zircons standards for U-Th-Pb, LuHf, trace elements and REE analysis. Geostandards Newsletter 19: 1-23.

Wilson, M. 1989. Igneous Petrogenesis. A global tectonic approach. Unwin Hyman. 466 pp.

Winchester, J.A. and Floyed, P.A. 1977. Geochemical discrimination of different magma series and their differentiation products using immobile elements, Chemical Geology, 20, 325-343.

Yavus, F. 2007. WinAmphcal: A windows program for the IMA-04 amphibole classification. Geochem.Geophys. Geosyst. volume 8, 1-12.

Yazgan, E. and R. Mason. 1988. Orbicular gabbro from near Baskil, southeastern Turkey. Mineralogical Magazine, 52,161-177.

Figure captions

Fig. 1. A. The northernmost outcrops of the Arabian Nubian Shield; B. Part of the Janub Metamorphic Complex which hosts the investigated gabbroic stocks (Ain Alhashim gabbro); C. a detailed map of the Rosetta gabbro locality.

Fig. 2. A. The intrusive contact of Abu Jedda Granite (AJG) into the Janub Metamorphic Complex (H); B. The Rosetta gabbro (RG) intruding into the Janub Metamorphic Complex and intruded by Abu Jedda Granite (AJG); C. a close up of the Rosetta gabbro as seen in outcrop. 
Fig. 3. U-Pb inverse (Terra and Wasserburg) Concordia plot for Abu-Jedda granite (HC41).

Fig 4. A. The rosetta gabbro as seen in the field; B. Polished slabs showing rosettas of various sizes, note the equatorial and non-equatorial sections in both; C. Expanded single rosetta showing the tabular shape and to some extent fan-shaped growth of the plagioclase.

Fig. 5. Textures of Rosetta Gabbro (A) and non-rosetta gabbro (B) A. scanned thin section of Rosetta Gabbro (HC-43) showing a small (left center) and a large rosetta (right). Central magnesiohornblende (Mhb) cores, tschermakite (Ts) is dark greenish brown in color; B. A scanned thin section of the non-rosetta hornblende gabbro (HC-31) showing both the tschermakite (brown) surrounded and replaced by magnesiohornblende with plagioclase $(\mathrm{Pl})$ that is often zoned. The zoning is obvious from the weathered core with a cloudy appearance and as confirmed by EMPA.

Fig. 6. Photomicrographs of Rosetta Gabbro (A-C) and normal hornblende gabbro (D). A. Plane-polarized light image of magnesiohornblende (Mhb) replacing tschermakite (Ts) (HC-43), the gray circle in the middle is a 40 micron laser ablation analysis spot ; B. Cross-polarized image showing anhedral aggregate of magnesiohornblende forming the cores of the rosettas; C. Cross-polarized image showing the perpendicular growth of tabular plagioclase crystals radiating from the amphibole core (HC-43); D. Crosspolarized image of ophitic and subophitic texture in non-rosetta gabbro (HC-31) where plagioclase laths are partially or completely enclosed in the tschermakite and/or magnesiohornblende. 
Fig. 7. Textural analysis for the purpose of estimating the plagioclase to amphibole ratio (Fig. 4B) prepared using the ImageJ software.

Fig. 8. Total alkalis $\backslash$-silica classification and AFM diagrams (Le Maitre et al., 1989; Irvine and Baragar, 1971); $\mathrm{P}_{2} \mathrm{O}_{5}$ vs $\mathrm{Zr}$ and $\mathrm{Zr} / \mathrm{Y}$ vs $\mathrm{Zr}$ diagrams (Pearce and Norry, 1979). Open triangles $=$ Rosetta Gabbro, Open circles $=$ non-rosetta gabbro .

Fig. 9. A. Chondrite-normalized pattern; B. MORB-normalized plot; and C. multielement spider diagram for the investigated gabbros. Open triangles $=$ Rosetta Gabbro, Open circles $=$ non-rosetta gabbro.

Fig. 10. Amphibole compositions plotted on the classification diagram of Leake et al., 1997. Open triangles $=$ Rosetta Gabbro, Open circles $=$ non-rosetta gabbro.

Fig. 11. $\mathrm{Al}^{\mathrm{VI}}$, Ti and A-site vs. tetrahedrally coordinated Al. Open triangles $=$ Rosetta Gabbro, Open circles $=$ non-rosetta gabbro.

Fig. 12. Variation diagrams of trace elements contents of amphiboles. Magnesiohornblende $=$ open triangles; tschermakite $=$ solid triangles. 
Fig. 13: REE in amphiboles and plagioclase (A, B, \&C) and spider plots (D \& E) of the rosetta gabbro Magnesiohornblende = open triangles; tschermakite = solid triangles .

Fig. 14: Summary model for formation of Rosetta Gabbro and non-rosetta hornblende gabbro of the Ayn-Al Hashim Gabbroic Suite. A: Two mafic intrusions are emplaced $\sim 600 \mathrm{Ma}$, one is water-rich but can easily degas via volcanic conduit (left) and one is drier and/or cannot easily degas (right). Both bodies crystallize tschermakite early but plagioclase crystallization is suppressed in one body because of high magmatic water pressures (left). The other magmatic body crystallizes plagioclase along with tschermakite (right). B: Magnesiohornblende crystallizes around tschermakite cores. In the case of one intrusion (left), this reflects influx of more primitive mafic magma from the mantle, which heats fractionated magma and causes it to degas, leading to a decrease in magmatic water pressure. C: Degassed magma becomes supersaturated in plagioclase, which nucleates on tshermakite-magnesiohornblende crystals suspended in magma.

Radial growth of plagioclase is rapid, lowering density of plagioclase amphibole rosettas and allowing them to remain suspended in magma. Prolonged suspension of rosettas in supersaturated magma leads to rapid growth of plagioclase. D: Abu Jedda granite intrudes gabbroic bodies $\sim 596$ Ma. E: $\sim 10 \mathrm{~km}$ of erosion in Late Ediacaran time results in present exposure. 